2015

How Teaching About Therapeutic Jurisprudence Can Be a Tool of Social Justice, and Lead Law Students to Personally and Socially Rewarding Careers: Sexuality and Disability as a Case Example

Michael L. Perlin

New York Law School

Alison Lynch

Follow this and additional works at: https://digitalcommons.nyls.edu/fac_articles_chapters

Part of the Legal Education Commons, and the Sexuality and the Law Commons

Recommended Citation

16 Nev. L.J. 209 (2015-2016)

This Article is brought to you for free and open access by the Faculty Scholarship at DigitalCommons@NYLS. It has been accepted for inclusion in Articles \& Chapters by an authorized administrator of DigitalCommons@NYLS. 


\title{
How TEACHING ABOUT THERAPEUTIC JURISPRUDENCE CAN BE A TOOL OF SOCIAL JUSTICE, AND LEAD LAW STUDENTS TO PERSONALLY AND SOCIALLY REWARDING CAREERS: SEXUALITY AND DISABILITY AS A CASE EXAMPLE
}

\author{
Michael L. Perlin* and Alison J. Lynch**
}

INTRODUCTION

We expect that no reader is surprised to learn that "so many eager and excited first-year law students become jaded and apathetic by the time they graduate from law school." ${ }^{1}$ Students" "early curiosity about law as a tool to engage pressing social issues fades as they become both disillusioned and passive over the course of their law school experience."2 Similarly, no one is surprised to learn that these problems are exacerbated by legal educators who often dismiss as irrelevant the students' "moral concerns or compassion for the people in the cases they discuss," leading others to focus on law schools - and the standard model of legal education - as the most important cause of cynicism and disillusionment in young lawyers. ${ }^{4}$ The traditional law school curriculum's emphasis

* Michael L. Perlin, Esq. is the Founding Director of the International Mental Disability Law Reform Project and is Professor Emeritus of Law at New York Law School, 185 West Broadway, New York, NY 10013, (212) 431-2183, michael.perlin@nyls.edu, mlperlin@mdlpa.net.

** Alison J. Lynch, Esq. is a Staff Attorney at Disability Rights New York, 25 Chapel Street, Suite 1005, Brooklyn, NY 11201, Alison.Lynch@ disabilityrightsny.org.

${ }^{1}$ Robin Wellford Slocum, An Inconvenient Truth: The Need to Educate Emotionally Competent Lawyers, 45 CREIGHTON L. REV. 827, 828 (2012).

${ }^{2}$ Susan Sturm, Commentary, Reaction: Law Schools, Leadership, and Change, 127 HaRv. L. REV. F. 49, 51 (2013).

${ }^{3}$ Slocum, supra note 1, at 839 n.59 (quoting William M. Sullivan ET AL., Carnegie FOUND. FOR THE ADVANCEMENT OF TEACHING, EDUCATING LAWYERS: PREPARATION FOR THE PROFESSION OF LAW 187 (2007)).

${ }^{4}$ Benjamin H. Barton, The ABA, the Rules, and Professionalism: The Mechanics of SelfDefeat and a Call for a Return to the Ethical, Moral, and Practical Approach of the Canons, 83 N.C. L. REv. 411, 443-44 (2005) (citing, inter alia, Susan Daicoff, Lawyer Know Thyself: 
on rules and analysis "erodes [students" pre-existing] sense of purpose, leaving many ... disillusioned and disengaged." As Stephen Siptroth has elegantly said, "the soul of the law student atrophies, withers, and disappears in a fog of dysfunction."

There is powerful evidence that legal education is overtly "harmful to the emotional and psychological well-being of many law students." Certainly, there is no disputing the research that the "incidence of clinically diagnosable depression among law students is much higher than among the general population." 8

Within a few months of entering law school, students begin to display significant symptoms indicating that the demands of school are taxing their adaptive capacity. ... Students also report extreme self-punishing attitudes, obsessive self-doubt, apathy, withdrawal from normal activities, fear, apprehension, a sense of impending doom, and panic attacks. ${ }^{9}$

Of course, these symptoms make learning more difficult. High levels of anxiety can interfere with memory and assimilation of material, making study difficult. ${ }^{10}$ Additionally, "thoughts and moods associated with depression and anxiety often are associated with behavioral avoidance - in this case, of law school

A Review of Empirical Research on Attorney Attributes Bearing on Professionalism, 46 AM. U. L. REV. 1337, 1386-87 \& nn. 293-301 (1997); Ruta K. Stropus, Mend It, Bend It, and Extend It: The Fate of Traditional Law School Methodology in the 21st Century, 27 LoY. U. CHI. L.J. 449, 455-65 (1996)). For a personal account, see RICHARD D. KAHLENBERG, Broken CONTRACT: A MEMOIR OF HARVARD LAW SCHOOL 236-38 (1999) (discussing how Harvard Law School stripped the author of his idealism and commitment to social justice).

5 Margaret Meriwether Cordray, Expanding Pro Bono's Role in Legal Education, 48 IDAHO L. REV. 29, 36 (2011) (citing SuSAN SwAIM DAICOFF, LAWYER KNOW THYSELF 76-77 (2004)).

${ }^{6}$ Stephen M. Siptroth, Note, Forming the Human Person: Can the Seminary Model Save the Legal Profession?, 2007 BYU EDUC. \& L.J. 181, 181 (2007).

${ }^{7}$ Cordray, supra note 5, at 36 n.25 (quoting RoY STUCKEY ET AL., BeST PRACTICES FOR LEGAL EDUCATION: A VISION AND A ROADMAP 29-36 (2007)).

${ }^{8}$ Michael H. Hoeflich, Legal Ethics and Depression, 74 J. KAN. B. Ass'N, Sept. 2005, at 33, 34 (citing G. Andrew H. Benjamin et al., The Prevalence of Depression, Alcohol Abuse, and Cocaine Abuse Among United States Lawyers, 13 INT'L J.L. \& Psychiatry 233, 234 (1990))

${ }^{9}$ Suzanne C. Segerstrom, Perceptions of Stress and Control in the First Semester of Law School, 32 WILLAMETTE L. REV. 593, 594 (1996) (footnotes omitted) (citing, inter alia, G. Andrew H. Benjamin et al., The Role of Legal Education in Producing Psychological Distress Among Law Students and Lawyers, AM. B. FounD. RES. J. 225, 240,247 (1986); Phyllis W. Beck \& David Burns, Anxiety and Depression in Law Students: Cognitive Intervention, 30 J. LEGAL EDUC. 270, 274-75, 276 (1979)).

${ }_{10}$ See Matthew Owens et al., Anxiety and Depression in Academic Performance: An Exploration of the Mediating Factors of Worry and Working Memory, 33 SCH. PSYCHOL. INT'L 433,433 (2012) ("Higher levels of anxiety and depression were associated with lower academic performance" for students in a variety of testing environments that relied on knowledge retention); see also Matthew Owens et al., When Does Anxiety Help or Hinder Cognitive Test Performance? The Role of Working Memory Capacity, 105 BRITISH J. PSYCHOL. 92, 92 (2014) ("Cognitive interference theories . . suggest that high levels of trait anxiety predict adverse effects on the performance of cognitive tasks ...."). 
itself." It is no wonder "some evidence suggests that rates of clinical depression and of alcohol and substance abuse rise regularly while students continue their legal education." 12

And there is more. Classes that are not "mainstream," such as private law and business-related courses, are referred to derisively as being about "law and bananas," 13 and are characterized as "esoteric fluff largely irrelevant to practice." 14 In a free-swinging attack on interdisciplinary education, Professor Arthur Austin sneered that he had "serious doubts about law professors possessing sufficient knowledge of the banana material to compose a credible syllabus" for a course. ${ }^{15}$ There is no question in our minds that this attitude is causally connected to the senses of anomie and misery felt by so many law students, as reflected in the research referred to above.

This gloom notwithstanding, the authors remain optimistic. We believe that there is a way out of this morass, a way that one of us (MLP) has used as a teacher (and that AJL, who was MLP's student before she became his coauthor and colleague, absorbed as a student). This way incorporates principles of therapeutic jurisprudence (TJ) into our teaching, our writing, and our law practice, in many areas of law, not just in mental disability law (where TJ began). ${ }^{16}$ We believe that the act of teaching TJ can be a tool of social justice, and

11 Segerstrom, supra note 9, at 595 n.20 (citing B.A. Glesner, Fear and Loathing in the Law Schools, 23 CONN. L. REV. 627, 636-37 (1991))

${ }^{12}$ Michael L. Perlin, "Baby, Look Inside Your Mirror": The Legal Profession's Willful and Sanist Blindness to Lawyers with Mental Disabilities, 69 U. PITT. L. REV. 589, 593 (2008) [hereinafter Look Inside Your Mirror] (citing, in part, Robert P. Schuwerk, The Law Professor as Fiduciary: What Duties Do We Owe to Our Students, 45 S. TEX. L. REv. 753, 764 (2004))

${ }^{13}$ See, e.g., Steven R. Smith, From Law and Bananas to Real Law: A Celebration of Scholarship in Mental Health Law, 34 CAL. W. L. REv. 1, 1 (1997) (criticizing this attitude).

${ }^{14}$ Deborah L. Rhode, Legal Education: Professional Interests and Public Values, 34 IND. L. REV. 23, 37 (2000).

15 Arthur Austin, The Alchemy of Promotion and Tenure, 75 DENVER U. L. REv. 1, 5 (1997).

${ }^{16}$ One of the authors (MLP) has written multiple articles using TJ principles in the areas of criminal procedure and international human rights law, for example. Perhaps not insignificantly, many of his co-authors of the articles cited infra are forensic psychologists and litigators, not law professors. See, e.g., Astrid Birgden \& Michael L. Perlin, 'Tolling for the Luckless, the Abandoned and Forsaked': Therapeutic Jurisprudence and International Human Rights Law As Applied to Prisoners and Detainees by Forensic Psychologists, 13 LFGAL \& CRIMINOLOGICAL PSYCHOL. 231, 234-38 (2008); Astrid Birgden \& Michael L. Perlin, "Where the Home in the Valley Meets the Damp Dirty Prison": A Human Rights Perspective on Therapeutic Jurisprudence and the Role of Forensic Psychologists in Correctional Settings, 14 AGgression \& Violent Behav. 256, 257-58 (2009); Michael L. Perlin \& Henry A. Dlugacz, "It's Doom Alone that Counts": Can International Human Rights Law Be an Effective Source of Rights in Correctional Conditions Litigation?, 27 BEHAV. SCI. \& L. 675, 691-94 (2009). See generally Michael L. Perlin, "Striking for the Guardians and Protectors of the Mind": The Convention on the Rights of Persons with Mental Disabilities and the Future of Guardianship Law, 117 PENN ST. L. REV. 1159 (2013) [hereinafter Striking]; Michael L. Perlin \& Valerie McClain, "Where Souls Are Forgotten": Cultural Competencies, Forensic Evaluations, and International Human Rights, 15 PSYCHOL. PUB. POL'Y \& L. 257 (2009); Michael L. Perlin, "Yonder Stands Your Orphan with His Gun": The International Human 
can lead students to more rewarding careers, both personally and socially. This article will consider these principles in the specific context of teaching and writing about sexuality and disability - a topic that has always been seen as "beyond the last frontier"

This article's basic thesis is that teaching TJ is a tool of social justice that can (1) help remediate traditional methods of law school teaching that have consistently led to apathy, depression, and anomie among students who learnboth implicitly and explicitly - that justice does not matter much in the process of teaching or learning law; (2) lead students to think critically and creatively about the range of social problems that are often ignored in traditional law school teaching; and (3) bring a sharp focus on a totally under-considered topic - the sexual autonomy rights of institutionalized persons with mental disabilities - in a way that may bring about important and emancipatory social change, possibly leading students to consider a career representing persons with such disabilities.

The article will proceed in the following manner. First, Part I gives a short overview of therapeutic jurisprudence. Then, Part II discusses New York Law School's course, Survey of Mental Disability Law (a course that MLP has taught, in multiple iterations, since 1985), its coverage, and student reactions to different topics presented. ${ }^{18}$ Part III considers how a TJ-based discussion of sexuality can sharpen students' understanding of the underlying issues, and building on that discussion, how those insights have informed both authors' scholarly writing on this substantive topic and AJL's public interest practice on behalf of persons with disabilities. The article then offers a brief conclusion and some thoughts for the future.

\section{THERAPEUTIC JURISPRUDENCE ${ }^{19}$}

Therapeutic jurisprudence "asks us to look at law as it actually impacts people's lives ${ }^{\prime 20}$ and focuses on the law's influence on emotional life and

Rights and Therapeutic Jurisprudence Implications of Juvenile Punishment Schemes, 46 TEX. TECH L. REV. 301 (2013).

${ }^{17}$ See generally Michael L. Perlin, Hospitalized Patients and the Right to Sexual Interaction: Beyond the Last Frontier?, 20 N.Y.U. REV. L. \& SoC'L CHANGE 517 (1993-94) [hereinafter Hospitalized Patients].

${ }^{18}$ New York Law School also offers a stand-alone course in Therapeutic Jurisprudence. See, e.g., Michael L. Perlin, "They Keep It All Hid": The Ghettoization of Mental Disability Law and Its Implications for Legal Education, 54 ST. LoUIS U. L.J. 857, $870 \mathrm{nn} .58-59$ (2010) [hereinafter They Keep It All Hid].

${ }^{19}$ Much of this section is adapted from Michael L. Perlin \& Alison J. Lynch, "Love Is Just a Four-Letter Word": Sexuality, International Human Rights, and Therapeutic Jurisprudence, 1 CANADIAN J. COMPARATIVE \& CONTEMPORARY L. 9 (2015).

${ }^{20}$ Bruce J. Winick, Foreword: Therapeutic Jurisprudence Perspectives on Dealing with Victims of Crime, 33 Nova L. REV. 535, 535 (2009). 
psychological well-being. ${ }^{21}$ It suggests that "law should value psychological health, should strive to avoid imposing anti-therapeutic consequences whenever possible, and when consistent with other values served by law, should attempt to bring about healing and wellness." 22 "The ultimate aim of therapeutic jurisprudence is to determine whether legal rules, procedures, and lawyer roles can or should be reshaped to enhance their therapeutic potential while not subordinating due process principles." 23

There is an inherent tension in this inquiry, but David Wexler clearly identifies how it must be resolved: The law's use of "mental health information to improve therapeutic functioning [cannot] imping[e] upon justice concerns." 24 As one of the authors has written elsewhere, "an inquiry into therapeutic outcomes does not mean that therapeutic concerns 'trump' civil rights and civil liberties." 25 In its aim to use the law to empower individuals, enhance rights, and promote well-being, TJ has been described as "a sea-change in ethical thinking about the role of law ... a movement towards a more distinctly relational approach to the practice of law ... which emphasi[zes] psychological wellness over adversarial triumphalism." 26 That is, TJ supports an "ethic of care."27

${ }^{21}$ See David B. Wexler, Practicing Therapeutic Jurisprudence: Psycholegal Soft Spots and Strategies, in Practicing TheraPeUtic JuRISPRUdenCE: LAW AS A HEl PING Profession 45, 45 (Dennis P. Stolle et al. eds., 2000).

${ }^{22}$ Bruce J. Winick, A Therapeutic Jurisprudence Model for Civil Commitment, in INVOLUNTARY DETENTION AND THERAPEUTIC JURISPRUDENCE: INTERNATIONAL PERSPECTIVES ON Civil Commitment 23, 26 (Kate Diesfeld \& Ian Freckelton eds., 2003).

${ }^{23}$ Striking, supra note 16, at 1184; accord Michael L. Perlin, "And My Best Friend, My Doctor/Won't Even Say What It Is I've Got": The Role and Significance of Counsel in Right to Refuse Treatment Cases, 42 SAN DIEGO L. REv. 735, 751 (2005) [hereinafter Best Friend]; Michael L. Perlin, "Everybody Is Making Love/Or Else Expecting Rain": Considering the Sexual Autonomy Rights of Persons Institutionalized Because of Mental Disability in Forensic Hospitals and in Asia, 83 WASH. L. REV. 481, 510 n.139 (2008) [hereinafter Expecting Rain]; see also Ian Freckelton, Therapeutic Jurisprudence Misunderstood and Misrepresented: The Price and Risks of Influence, 30 T. JEFFERSON L. REV. 575, 585-86 (2008); Look Inside Your Mirror, supra note 12, at 591 (discussing how TJ "might be a redemptive tool in efforts to combat sanism, as a means of 'stripping bare the law's sanist façade" "); Bernard P. Perlmutter, George's Story: Voice and Transformation Through the Teaching and Practice of Therapeutic Jurisprudence in a Law School Child Advocacy Clinic, 17 ST. Thomas L. REV. 561, 599 n.111 (2005).

${ }^{24}$ David B. Wexler, Therapeutic Jurisprudence and Changing Conceptions of Legal Scholarship, 11 BEHAV. SCI. \& L. 17, 21 (1993). See generally David B. Wexler, Applying the Law Therapeutically, 5 APPLIED \& PREVENTIVE PSYCHOL. 179 (1996).

${ }^{25}$ Michael L. Perlin, A Law of Healing, 68 U. CIN. L. REv. 407, 412 (2000); Michael L. Perlin, "Where the Winds Hit Heavy on the Borderline": Mental Disability Law, Theory and Practice, "Us" and "Them," 31 Loy. L.A. L. REv. 775, 782 (1998).

${ }^{26}$ Warren Brookbanks, Therapeutic Jurisprudence: Conceiving an Ethical Framework, 8 J.L. \& MED. 328, 329-30 (2001); see also Bruce J. Winick, Overcoming Psychological Barriers to Settlement: Challenges for the TJ Lawyer, in THE AFFECTIVE AssisTANCE of Counsel: Practicing Law as a Healing Profession 341, 341 (Marjorie A. Silver ed., 2007); Bruce J. Winick \& David B. Wexler, The Use of Therapeutic Jurisprudence in Law 
One of the central principles of TJ is a commitment to dignity. ${ }^{28}$ Professor Amy Ronner stresses the importance of the "three Vs" as voice, validation, and voluntariness, ${ }^{29}$ arguing:

What "the three Vs" commend is pretty basic: litigants must have a sense of voice or a chance to tell their story to a decision maker. If that litigant feels that the tribunal has genuinely listened to, heard, and taken seriously the litigant's story, the litigant feels a sense of validation. When litigants emerge from a legal proceeding with a sense of voice and validation, they are more at peace with the outcome. Voice and validation create a sense of voluntary participation, one in which the litigant experiences the proceeding as less coercive. Specifically, the feeling on the part of litigants that they voluntarily partook in the very process that engendered the end result or the very judicial pronunciation that affects their own lives can initiate healing and bring about improved behavior in the future. In general, human beings prosper when they feel that they are making, or at least participating in, their own decisions. ${ }^{30}$

The question to be addressed here is this: given the way we deny the sexuality rights of persons with disabilities, ${ }^{31}$ is it remotely possible that Professor Ronner's vision of voice, voluntariness, and validation will be fulfilled? Think about some of the ways that a radical change in the way we treat persons with disabilities in matters of sexuality can comply with TJ values. In a thoughtful analysis of the underlying issues, Professors Julie Tennille and Eric Wright have listed multiple benefits of a "communicative climate" for consumers with regard to sexuality issues. ${ }^{32}$ Professors Janine Benedet and Isabel Grant have

School Clinical Education: Transforming the Criminal Law Clinic, 13 CLINICAL L. REv. 605, 605-06 (2006).

${ }^{27}$ See, e.g., Gregory Baker, Do You Hear the Knocking at the Door? A "Therapeutic" Approach to Enriching Clinical Legal Education Comes Calling, 28 WHITTIER L. REV. 379, 385 (2006); Brookbanks, supra note 26; David B. Wexler, Not Such a Party Pooper: An Attempt to Accommodate (Many of) Professor Quinn's Concerns About Therapeutic Jurisprudence Criminal Defense Lawyering, 48 B.C. L. REv. 597, 599 (2007); Winick \& Wexler, supra note 26, at 605-07. The use of the phrase dates to CAROL GILLIGAN, IN A DIFFERENT VOICE (1982).

${ }^{28}$ See Bruce J. Winick, Civil Commitment: A Therapeutic Jurisprudence Model 161 (2005).

29 Amy D. Ronner, The Learned-Helpless Lawyer: Clinical Legal Education and Therapeutic Jurisprudence as Antidotes to Bartleby Syndrome, 24 TOURO L. REV. 601, 627 (2008). On the importance of "voice," see Freckelton, supra note 23, at 588.

${ }^{30}$ Amy D. Ronner, Songs of Validation, Voice, and Voluntary Participation: Therapeutic Jurisprudence, Miranda and Juveniles, 71 U. CIN. L. REV. 89, 94-95 (2002) (footnotes omitted).

31 See generally Michael L. Peri in \& Alison J. Lynch, Sexualtity, Disability and the LAW: BEYOND THE LAST FRONTIER? (forthcoming Jan. 2016); Michael L. Perlin \& Alison J. Lynch, "All His Sexless Patients": Persons with Mental Disabilities and the Competence to Have Sex, 89 WASH. L. REV. 257 (2014).

32 See Julie Tennille \& Eric Wright, Addressing the Intimacy Interests of People with Mental Health Conditions: Acknowledging Consumer Desires, Provider Discomforts, and System Denial, Temple Univ. Collaborative on CMTy. InClusion of Individuals with PSYCHIATRIC DISABILITIES 13-14 (2013), http://tucollaborative.org/pdfs/Toolkits_Mono graphs_Guidebooks/relationships_family_friends_intimacy/intimacy.pdf. 
also used a therapeutic jurisprudential filter in weighing these issues, and have considered how to define "capacity to consent" and "engage in sexual activities," and how to ensure that such definitions remain person-centered and allow for a "situational approach" to each case. ${ }^{33}$ They write that "incapacity can and should be defined situationally - in a functional manner that maximizes [a person's] sexual self-determination." ${ }^{34}$ However, Benedet and Grant's thoughtful analysis and emphasis on the individual and self-determination-two concepts linked with dignity ${ }^{35}$ - have not been greatly expanded upon in case law or legislation so as to give life to the therapeutic jurisprudential lens that they employ to view these issues of sexuality.

Over twenty years ago, one of us (MLP) wrote the following about sexuality issues in the domestic context, and we believe that little has changed in the intervening two decades:

We must also question the therapeutic or antitherapeutic implications of official hospital policies that control the place, manner, and frequency with which such individuals can have sexual interactions. We must consider the implications of these policies on ward life and their implications for patients' post-hospital lives. These questions are difficult ones, but we must ask them nonetheless if we wish to formulate a thoughtful, comprehensive response to the wide range of questions this subject raises. ${ }^{36}$

- Healthy sexual relationships can foster development and maintenance of new relationships, a key element in social integration;

- Positive sexual partnerships can increase quality of life, and those with mental health conditions who maintain relationships often have better treatment outcomes;

- Some research indicates that hospital readmission rates dropped if consumers were able to develop romantic relationships; and

- Stigma of mental illness may be reduced.

Id. (citations omitted).

33 Janine Benedet \& Isabel Grant, A Situational Approach to Incapacity and Mental Disability in Sexual Assault Law, 43 OtTAwa L. Rev. 1, 3-4 (2011-13).

${ }^{34} I d$. at 4.

${ }^{35}$ On the role of dignity in mental disability law in general, see MiCHAEL L. PERLIN, A PRESCRIPTION FOR Dignity: RETHINKING CRIMINAL Justice and MENTAL Disability LaW (2013). On its role in therapeutic jurisprudence, see, for example, WINICK, supra note 28; Claire B. Steinberger, Persistence and Change in the Life of the Law: Can Therapeutic Jurisprudence Make a Difference?, 27 L. \& PsycHOL. REV. 55, 64 (2003) (describing TJ's focus on psychological and social outcomes as including "feelings of dignity and self-worth").

${ }^{36}$ Hospitalized Patients, supra note 17, at 547. On the range of therapeutic jurisprudencerelated issues that are related in general to institutional decision-making in matters involving sexual autonomy and issues of hospital security, see Expecting Rain, supra note 23. On the TJ questions related to hospital security questions in general, see Michael L. Perlin \& Alison J. Lynch, "Toiling in the Danger and in the Morals of Despair": Risk, Security, Danger, the Constitution, and the Clinician's Dilemma, 27 STAN. L. \& POL'Y REV. (forthcoming 2016). 


\section{Teaching Mental Disability LAW}

New York Law School has offered thirteen courses as part of a blended online mental disability law curriculum. ${ }^{37}$ The "gateway" course is Survey of Mental Disability Law, a course that seeks to provide "a comprehensive look at many of the issues that will be considered at greater length in the more specialized classes, and provides the basic doctrines fundamental to the understanding of mental disability law." 38 This course covers civil commitment, institutional rights (including the right to treatment, the right to refuse treatment, the right to sexual interaction, and others), deinstitutionalization, aftercare, federal statutory rights (with specific focus on the Americans with Disabilities Act), and the role of mental disability in the criminal trial process (including criminal incompetencies, insanity defense, federal sentencing guidelines, and the death penalty). ${ }^{39}$ All topics are taught from multiple theoretical perspectives; on the first day, students are taught the meaning of sanism, and how it infects the entire legal process and the legal academy. ${ }^{40}$ It is often new to students, but generally they reflect understanding via a discussion of sanist myths, parallels to other "isms," in the context of case and lawyering examples. ${ }^{41}$ This is closely followed by explanations of pretextuality, ${ }^{42}$ the way that heuristic thinking contaminates this area of law, ${ }^{43}$ the role of false "ordinary common sense," ${ }^{44}$ and, as a vehicle through which to integrate all the other material, the meaning of

\footnotetext{
37 They Keep It All Hid, supra note 18, at 865-71 (listing all courses).

${ }^{38} I d$. at 870 n. 58 .

${ }^{39} I d$.

40 Sanism is an "irrational prejudice of the same quality and character of other irrational prejudices that cause (and are reflected in) prevailing social attitudes of racism, sexism, homophobia, and ethnic bigotry." Id. at 860-61; see Michael L. Perlin, On "Sanism," 46 SMU L. REV. 373, 374-75 (1992).

41 See generally Michael L. Perlin, The Hidden PreJudice: Mental Disability on Trial (2000) (ways that both lawyers and judges discount and trivialize the experiences of persons with mental illness); see also Best Friend, supra note 23, at 738 (discussing the paternalism omnipresent in decisions that are made ostensibly on behalf of persons with mental illness).

42 "Pretextuality defines the ways in which courts accept (either implicitly or explicitly) testimonial dishonesty and engage similarly in dishonest (and frequently meretricious) decision-making. In many cases, courts allow witnesses, especially expert witnesses, to purposely distort their testimony in order to achieve desired ends." Michael L. Perlin, "Simplify You, Classify You": Stigma, Stereotypes and Civil Rights in Disability Classification Systems, 25 GA. ST. U. L. REV. 607, 621 (2009).

43 " 'Heuristics' is a cognitive psychology construct that refers to the implicit thinking devices that individuals use to simplify complex, information-processing tasks." Michael $\mathrm{L}$. Perlin, The Sanist Lives of Jurors in Death Penalty Cases: The Puzzling Role of "Mitigating” Mental Disability Evidence, 8 Notre Dame J.L. ETHICs \& Pub. POL'y 239, 254 (1994).

44 "[O]rdinary common sense" is a " "prereflective attitude' exemplified by the attitude of "What I know is "self-evident"; it is "what everybody knows."," Keri K. Gould \& Michael L. Perlin, "Johnny's in the Basement/Mixing Up His Medicine": Therapeutic Jurisprudence and Clinical Teaching, 24 SEATTLE U. L. REV. 339, 357 (2000) (citing Richard K. Sherwin, Dialects and Dominance: A Study of Rhetorical Fields in the Law of Confessions, 136 U. PA. L. REV. 729, 737 (1988)).
} 
therapeutic jurisprudence. The "bottom line" remains this: "All aspects of mental disability law are pervaded by sanism and by pretextuality, whether the specific presenting topic is involuntary civil commitment law, right to refuse treatment law, the sexual rights of persons with mental disabilities, or any aspect of the criminal trial process. ${ }^{45}$

There are sometimes some bumps in the course of teaching the right-torefuse-treatment unit as the result of the vividness heuristic ${ }^{46}$ at work (e.g., "But what about that creepy guy on the subway this morning?" and/or "Professor, you never met my brother-in-law, who ..."), but they abate as students learn about the case law and the reasons it arose (focusing on the pervasiveness of toxic side effects revealed in institutional drugging cases, and how, institutionally, medication is often used as a means of social control rather than as treatment) ${ }^{47}$ Even in the discussions of the insanity defense, when students learn how the common wisdom (as to rate of the plea being used, success rates, dispositions, and malingering) is all wrong, ${ }^{48}$ they recognize that they previously had fallen prey to the power of the vividness heuristic. ${ }^{49}$ But, notwithstanding these attitudinal changes, the only topic receiving a "what are you, kidding?" response comes when the discussion turns - in the unit on "other institutional rights" - to the right of institutionalized patients to sexual autonomy. ${ }^{50}$

This is, to many students, again, beyond the last frontier. The notion that patients have such a right - and that this right may be found in some state patients' bills of rights ${ }^{51}$ and may be further supported by ADA-based argu-

${ }^{45}$ Best Friend, supra note 23 (emphasis added).

${ }^{46}$ The vividness heuristic is the cognitive-simplifying device through which a "single vivid, memorable case overwhelms mountains of abstract, colorless data upon which rational choices should be made." Michael L. Perlin, "The Borderline Which Separated You from Me": The Insanity Defense, the Authoritarian Spirit, the Fear of Faking, and the Culture of Punishment, 82 IOWA L. REV. 1375, 1417 (1997).

${ }^{47}$ See, e.g., Michael L. Perlin, The ADA and Persons with Mental Disabilities: Can Sanist Attitudes Be Undone?, 8 J.L. \& HEALTH 15, 43 n.163 (1993-94) (discussing how, in the lead right-to-refuse involuntary medication case of Rennie v. Klein, 476 F. Supp. 1294, 1299 (D.N.J. 1979) (establishing broad constitutionally-based right to refuse antipsychotic drug treatment), the "medical director of defendant institution acknowledged that medication was used 'as a form of control and as a substitute for treatment" ").

48 See generally Michael L. PerLin, The JuRisprudenCe of The Insanity DeFEnSE (1994).

49 See, e.g., Michael L. Perlin, "His Brain Has Been Mismanaged with Great Skill": How Will Jurors Respond to Neuroimaging Testimony in Insanity Defense Cases?, 42 AKRON L. REV. 885, 903 (2009).

${ }^{50}$ This attitude similarly prevails in student responses in the course on Sex Offenders, where the vast majority of students enter that class with the idée fixe that the television series, Law and Order: $S V U$, is 100 percent right about everything, failing to acknowledge that this may not be the whole story. On media contamination of public attitudes towards sex offender litigation and legislation in general, see, for example, Heather Ellis Cucolo \& Michael L. Perlin, "They're Planting Stories in the Press": The Impact of Media Distortions on Sex Offender Law and Policy, 3 U. DENV. CRIM. L. Rev. 185, 217 (2013).

51 Hospitalized Patients, supra note 17, at 530. 
ments ${ }^{52}$-strikes many students as incredulous. ${ }^{53}$ It is stressed that their responses are textbook examples of sanism, but usually to no avail. But then, when they are reminded of Professor Amy Ronner's "three Vs," sometimes (just sometimes) there is some acceptance of the idea. ${ }^{54}$

Sanism has always pervaded the entire legal academy:

Last year, I was sitting at my faculty lunch table, and conversation turned to upcoming presentations that we would soon be doing. My colleagues mostly take left-liberal positions on a wide variety of issues, and are generically the exact mix of retro ' 60 s generationists and early baby boomers that you'd expect. They (appropriately) are quick to criticize any behavior that is racist, sexist, ethnically bigoted or homophobic. Rush Limbaugh would probably view them as one of his worst "politically correct" horror fantasies. As you might expect, I'm not terribly out of place in this group ....

Anyway, when it got to be my turn, I said that I was going to be speaking about the right of institutionalized mentally disabled persons to sexual interaction. All conversation came to a screeching halt.

"Michael, are you serious?" "Are you crazy (sic)?" "Michael, even for you, you've gone too far!" "What are you going to say next: that they can get married?!?" Et cetera. ${ }^{55}$

Although there are very few topics that remain taboo or off-limits to legal scholars, discussions of the question of whether persons with mental disabilities have a right to voluntary sexual interaction continues to touch a raw nerve in conversations about mental disability law - even with those who are practicing in the field. Why is this? In prior articles, we have explored this remarkable state of events. We discussed it in a recent article in the context of sanism, and we think it is necessary to keep this in mind as part of this conversation:

If as I saw it, sanist myths, based on stereotypes, are the result of rigid categorization and overgeneralization, then they function psychologically to "localize our anxiety, to prove to ourselves that what we fear does not lie within."

\footnotetext{
52 See Michael L. Perlin, "Make Promises by the Hour": Sex, Drugs, the ADA, and Psychiatric Hospitalization, 46 DEPAUL L. REV. 947, 947-48 (1997).

53 A careful body-language observer would quickly pick this up.

${ }^{54}$ Responses to grand rounds presentations that were done at hospitals and medical schools about these sexual rights have been startling. Perlin \& Lynch, supra note 31, at 258-61, 259 n.7.

When [MLP] gave this talk at the Florida Institute of Mental Health (part of the University of South Florida in Tampa), an audience member (from the general public) leapt to his feet, and denounced [him]: "Professor Perlin, you are an agent of the devil!" At a New York City hospital presentation, a nurse folded her arms across her chest, and announced, "Professor, you are the very embodiment of evil!"

Michael L. Perlin, "Limited in Sex, They Dare": Attitudes Toward Issues of Patient Sexuality, 26 AMER. J. FoRENs. PSYCHIATRY 25, 36 (2005) (recounting these and other examples). We discuss these issues extensively in PERLIN \& LYNCH, supra note 31.

${ }^{55}$ Michael L. Perlin, "You Have Discussed Lepers and Crooks": Sanism in Clinical Teaching, 9 CLINICAL L. REV. 683, 714 (2003).
} 
We thus labeled individuals with mental illness as "deviant, morally weak, sexually uncontrollable and emotionally unstable." And often, we (especially professionals) regard them as not being human at all, and lacking human qualities including needs for affection and dignified ways of expressing affection. Our attitudes toward the sexuality of persons with mental disabilities reflect this labeling:

Society tends to infantilize the sexual urges, desires, and needs of the mentally disabled. Alternatively, they are regarded as possessing an animalistic hypersexuality, which warrants the imposition of special protections and limitations on their sexual behavior to stop them from acting on these "primitive" urges. By focusing on alleged "differentness," we deny their basic humanity and their shared physical, emotional, and spiritual needs. By asserting that theirs is a primitive morality, we allow ourselves to censor their feelings and their actions. By denying their ability to show love and affection, we justify this disparate treatment. ${ }^{56}$

\section{TEACHING SEXUALITY THROUGH A THERAPEUTIC JURISPRUDENCE FILTER}

\section{A. From the Perspective of a Teacher}

For the week in the Survey of Mental Disability Law course in which the right to sexual interaction is taught, students are given these learning objectives:

- Understand how courts and legislatures have construed one of the most controversial aspects of institutional patients' rights law.

- Recognize how our response to questions of disability and sexuality i1luminates many of the underlying attitudinal issues that shape mental disability law policy.

- Identify "incredible dilemmas" (apparently irresolvable policy conflicts) that may be raised in institutional patients' rights inquiries. ${ }^{57}$

In addition, they are presented with three "directed study questions" that will, to an important extent, be the focus of that week's class discussion:

- What are the larger implications of the public's use of contradictory stereotypes in its consideration of issues of patient sexuality?

- Why do you think there has been so little litigation in this area of the law?

- Imagine that Foy v. Greenblott ${ }^{58}$ had been appealed to the California Supreme Court, and that you were a judge on that court at that time. How would you have decided that case on further appeal $?^{59}$

\footnotetext{
${ }^{56}$ Perlin \& Lynch, supra note 31, at 259-60 (footnotes omitted).

${ }^{57}$ Michael L. Perlin, Survey of Mental Disability Law Course Webpage Syllabus (Fall 2015) (copy on file with author).

${ }^{58} 190$ Cal. Rptr. 84, 91 (Ct. App. 1983) (institutionalized patient's right to engage in voluntary sexual relations required that she be afforded suitable opportunities for interactions with members of the opposite sex); see Hospitalized Patients, supra note 17, at 532-33.

59 See Perlin, supra note 57.
} 
These issues are all discussed in class through the filter of therapeutic jurisprudence. Students also consider a variety of other substantive questions about sexuality and disability law in the same manner. Depending on the semester, these questions may include the following:

- "Does it make a difference if we are discussing monogamous heterosexual sex, polygamous heterosexual sex, monogamous homosexual sex, polygamous homosexual sex, or bisexual sex?"60

- "Should erotic or pornographic material be made available to patients?" 61

- "Should a patient's decision to engage in what is sometimes perceived as 'deviant' sexual behavior subsequently be used as evidence of their danger either to self or others or of 'grave disability'?" 62

- "How should 'competency' be assessed in the context of patients' ability to consent to sexual activity?"63

- "To what extent are international human rights instruments of significance in assessing the extent to which institutionalized patients can exercise a right to sexual autonomy?"64

In each of these instances, students are asked to consider-through a therapeutic jurisprudence filter-whether persons with mental disabilities are given authentic autonomy in their sexual decision-making and whether Professor Ronner's "three Vs," discussed earlier, ${ }^{65}$ are complied with.

\footnotetext{
${ }^{60}$ Perlin \& Lynch, supra note 31, at 265.

${ }^{61} I d$.

${ }^{62}$ Id. See generally Michael L. Commons et al., Professionals' Attitudes Towards Sex Between Institutionalized Patients, 46 AM. J. PsYCHOTHERAPY 571 (1992) (discussing ways that mental health professionals' attitudes towards sex are influenced by the nature of the sexual activity and the patients' sexual orientation).

${ }^{63}$ Perlin \& Lynch, supra note 31, at 263 (discussing full range of issues to be considered in this context).

The most important recent developments have come in the case of Kortner v. Martise, 91 A.3d 412 (Conn. 2014). In Kortner, the plaintiff, administratrix of the estate of her daughter (the alleged victim [Kendall] and a person with mental disabilities) filed a complaint against a defendant for sexual battery, civil assault, and intentional infliction of emotional distress, stemming from a sadomasochistic sexual relationship that developed between victim and defendant, argued that her daughter had been legally unable to consent to sexual conduct. $I d$. at 412,445 . The court rejected this position, concluding that it was a "factual question for the jury to decide based on the nature of the particular conservatorship and the abilities of the conserved person," and noting that conservatorships need to be exercised via the "least intrusive means available by which the individual's affairs can be handled." Id. at 445 ; accord 2 Michael L. Perlin \& Heather Ellis Cucolo, Mental Disability Law: Civil and CRIMINAL \& 3C-5.1 n.251 (2d ed. Supp. 2014).

${ }^{64}$ Perlin \& Lynch, supra note 31, at 273-77.

${ }^{65}$ See supra notes 28-33 and accompanying text.
} 


\section{B. From the Perspective of a Former Student}

A central question for legal educators has been whether law schools can teach their students to "do good." ${ }^{66}$ Further, scholars ask, should schools feel as if they must impress upon students the importance of social justice work? ${ }^{67}$ Marginalized groups, like those with a mental disability ${ }^{68}$ are not highlighted as needing legal assistance and are not made a priority. The American Bar Association supports the promotion of public interest work. In its Commission on Professionalism report, it wrote "[t]he practice of law 'in the spirit of a public service' can and ought to be the hallmark of the legal profession." ${ }^{\prime 9}$ However, this endorsement of public service has, by and large, not made it to law schools. The culture of legal education, especially at a time when economic success for graduates is so highly relevant, and job placement statistics are so carefully scrutinized by law blogs and the popular legal press, ${ }^{70}$ does not promote public interest work. $^{71}$

Some legal educators may feel that if a student has not developed "the idealism, the willingness to forego financial rewards and social respectability, and the commitment to social justice that motivate and sustain lawyers" who choose careers in public interest, no amount of encouragement from a law school will instill this. ${ }^{72}$ However, this is simply not the case, nor is there any valid or reliable empirical evidence supporting it. It is unreasonable to believe that students cannot be motivated to pursue careers in public interest once they attend law school and see firsthand the need for such services. To imply that students cannot be motivated by what they experience in the classroom, in clinical work, and in internships is to conclude that no amount of encouragement by professors and administrators can get students into public interest careers.

${ }^{66}$ Stephen Wizner, Can Law Schools Teach Students to Do Good? Legal Education and the Future of Legal Services for the Poor, 3 N.Y. CITY L. REv. 259, 259 (2000)

${ }^{67} I d$. at 259-60.

${ }^{68}$ See, e.g., Michael L. Perlin \& John Douard, "Equality, I Spoke That Word/As if a Wedding Vow": Mental Disability Law and How We Treat Marginalized Persons, 53 N.Y.L. SCH. L. REv. 9, 10 (2008-09). See generally Michael L. Perlin, Competency, Deinstitutionalization, and Homelessness: A Story of Marginalization, 28 Hous. L. REv. 63 (1991).

${ }^{69}$ ABA COMm'N ON Professionalism, “.... IN THE SPIRIT OF Public Service:" A BLUEPRINT FOR THE REKINDLING OF LAWYER PROFESSIONALISM 10 (1986).

70 See generally Jeff Schmitt, Law Schools Where Grads Actually Get Jobs, TIPPING THE SCALES (Mar. 13, 2014), http:/tippingthescales.com/2014/03/law-schools-where-grads-getjobs; Jordan Weissmann, The Jobs Crisis at Our Best Law Schools Is Much, Much Worse than You Think, THE ATLANTIC (Apr. 9, 2013), http:/www.theatlantic.com/business/archive 2013/04/the-jobs-crisis-at-our-best-law-schools-is-much-much-worse-than-youthink/274795; Staci Zaretsky, Which Law Schools Employed the Most Graduates As Real Lawyers Versus Real Baristas, ABove THE LAW (Mar. 27, 2013, 1:09 PM), http://abovethelaw.com/2013/03/which-law-schools-employed-the-most-graduates-as-reallawyers-versus-real-baristas.

${ }^{71}$ Jill Chaifetz, The Value of Public Service: A Model for Instilling a Pro Bono Ethic in Law School, 45 StAN. L. REV. 1695, 1697 (1993).

72 Wizner, supra note 66, at 260. 
That conclusion is a disservice to legal pedagogy. Rather than conclude that students have a predetermined career path upon entering law school, professors and administrators need to recognize their potential for impact, and create a culture and classroom pedagogy that support their goals of directing students toward meaningful public interest careers.

The task of reforming current legal pedagogy and teaching law students how to "do good" may seem daunting, but tools in the fields of social justice and public interest already exist, such as clinics and other experiential courses, ${ }^{73}$ courses on professional responsibility,${ }^{74}$ and therapeutic jurisprudence. ${ }^{75}$ $\mathrm{TJ}$ is a powerful teaching tool because it combines law's known qualities, and inherent power imbalances, with the need to recognize those qualities and adapt them to create a therapeutic benefit for the client. ${ }^{76}$

Therapeutic jurisprudence, in particular, can also be integrated into the curriculums of many existing classes, even including the core classes that students must complete in their first year. ${ }^{77}$ TJ transcends many topics of law, and should not be limited to use when discussing only cases involving mental disability. ${ }^{78} \mathrm{TJ}$ can be an important tool in family law, criminal law, wills and trusts law, gay rights law, torts law, and others. ${ }^{79}$ This provides multiple opportunities for professors across the substantive disciplines to teach TJ principles and client-centered lawyering. Connecting and empathizing with a client will only help to create a feeling of connectedness between a law student and the individuals she may have the opportunity to represent in her career. Making stu-

${ }^{73}$ Fran Quigley, Seizing the Disorienting Moment: Adult Learning Theory and the Teaching of Social Justice in Law School Clinics, 2 CLINICAL L. REv. 37, 38 (1995); Antoinette Sedillo Lopez, Learning Through Service in a Clinical Setting: The Effect of Specialization on Social Justice and Skills Training, 7 CLINICAL L. REV. 307, 308 (2001); Stephen Wizner \& Jane Aiken, Teaching and Doing: The Role of Law School Clinics in Enhancing Access to Justice, 73 FoRDHAM L. REV. 997, 997 (2004).

74 See Tanina Rostain, Ethics Lost: Limitations of Current Approaches to Lawyer Regulation, 71 S. CAL. L. REV. 1273, 1274 (1998).

75 See Perlin \& Douard, supra note 68, at 14 ("The use of TJ-as a tool for the exposure of these hoaxes and as a mechanism for advancing social justice is a way (perhaps the only way) to redeem the law for persons who have been marginalized.").

${ }^{76}$ On the relationship between TJ and power imbalances, see, for example, Jamie Balson, Therapeutic Jurisprudence: Facilitating Healing in Crime Victims, 6 PHOENIX L. REV. 1017, 1024 (2013).

${ }^{77}$ Indeed, David Wexler, one of the founders of TJ, has been focusing on this precise point in his recent scholarship. See, e.g., Dennis P. Stolle et al., Integrating Preventive Law and Therapeutic Jurisprudence: A Law and Psychology Based Approach to Lawyering, 34 CAL. W. L. REv. 15, 49 (1997); David B. Wexler, The International and Interdisciplinary Project to Mainstream Therapeutic Jurisprudence (TJ) in Criminal Courts: An Update, a Law School Component, and an Invitation, in ESSAYS ON THERAPEUTIC JURISPRUDENCE IN NEW ZEALAND (Warren Brookbanks ed., 2015 forthcoming), http://papers.ssrn.com/sol3/papers .cfm?abstract_id=2399914

${ }^{78}$ Elizabeth F. Schwartz, Book Review, Practicing Therapeutic Jurisprudence: Law As a Helping Profession, 76 FLA. B.J., Jan. 2002, at 66, 66.

${ }^{79}$ See Michael L. Perlin, "Things Have Changed:" Looking at Non-Institutional Mental Disability Law Through the Sanism Filter, 46 N.Y.L. SCH. L. REV. 535, 543-45 (2003). 
dents aware of the issues regarding access to justice and equality that exist, starting from their first-year core classes, will serve as a foundation for TJ teachings and discussions about strategies and goals for addressing these problems. Learning to give clients dignity, voice, and validation will be critical skills to developing the empathy that can lead students to choose to pursue careers in public interest law. Moreover, teaching about sexuality and disability in a therapeutic jurisprudence context is, to us, a perfect way of making these points.

Law schools will also need to take responsibility for proactively reforming and reshaping their curriculum and career planning. ${ }^{80}$ Integrating social justice and TJ values into the curriculum will set students up to continue their education with these values in mind. These changes can be made in a practical manner by focusing on what values students should be learning, and developing strategies to teach them. Professors can create new classes that delve into the problems facing marginalized groups, and the strategies lawyers can employ when representing them. Existing courses can be modified to include discussions based on cases already assigned that highlight a social justice problem.

It is also important to recognize that students do not have to choose either public interest or private practice. There can be some of each, even for a student who feels compelled to enter private practice as his or her primary career. Pro bono opportunities within firms, or through bar organizations, should be encouraged and highlighted by career offices at law schools when speaking with students about postgraduate plans. ${ }^{81}$

Many law schools already teach the benefits of employing a client-centered approach to lawyering, so integrating TJ themes in this framework is not a difficult task. ${ }^{82}$ Classes that teach professional responsibility and ethics can also highlight the balancing necessary for adhering to the legal rules of conduct and ensuring that marginalized clients receive the best possible advocacy. Clinics can teach not only the theory, but the practical elements of public interest work, such as the strategies employed at pretrial hearings, the way to properly question an expert during a commitment hearing, how to engage in a dialogue with a client in an incompetency or insanity case, ${ }^{83}$ and the evolving jurisprudence around sexual autonomy for individuals with mental disabilities. Exposure, education, and information can be "transformative" for students. ${ }^{84}$

Law schools have a responsibility to teach students about not only the power of the law through legislation and judicial decisions, but also about the

${ }^{80}$ Wizner, supra note 66 , at 263.

${ }^{81} I d$. at 266.

${ }^{82}$ See generally, Robert A. Baruch Bush, Mediation Skills and Client-Centered Lawyering: A New View of the Partnership, 19 CLINICAL L. REV. 429 (2013).

${ }^{83}$ See, e.g., Michael L. Perlin, "Too Stubborn to Ever Be Governed By Enforced Insanity": Some Therapeutic Jurisprudence Dilemmas in the Representation of Criminal Defendants in Incompetency and Insanity Cases, 33 INT'L J. L. \& PSYCHIATRY 475, 480 (2010).

${ }^{84}$ Wizner, supra note 66, at 264. 
social responsibility that comes with exercising such power. ${ }^{85}$ Where groups of marginalized individuals are concerned, power often comes into play-for example, the power to hold an indigent defendant without bail even though statistically this all but ensures a worse case disposition ${ }^{86}$ or the power to civilly commit an individual and deprive him of significant liberty interests. ${ }^{87}$ Law students need to be made aware of these injustices that exist in the law, and the power an attorney has to work to correct them. ${ }^{88}$ This power permeates the practice of law, and if taught appropriately, students can and should be encouraged to harness it to serve disadvantaged individuals. ${ }^{89}$ Learning through the use of therapeutic jurisprudence can help students recognize the inherent power imbalances in the law and combine their training to "think like lawyers" ${ }^{" 90}$ with the empathy and understanding that $\mathrm{TJ}$ promotes.

One of us (AJL) is still relatively new to the practice of law, having graduated in 2013. While the law school culture at that time recognized the inherent value of public interest work, it was clear that the majority of students planned to enter private practice. Classes that integrated social justice issues and teachings from TJ were beginning to be implemented and, more importantly, were beginning to draw interest from students who had jobs in the private sector, and though it is impossible to know how many career trajectories changed because of them, these courses at least reinforced the importance of public interest work and pro bono obligations. Additionally, students who took these classes will no doubt be more skilled, more empathetic, and better able to recognize the inherent inequalities in the legal system, no matter what field they choose to enter.

Reforming and reshaping the way that public interest work is offered and presenting it as a viable career choice will be a crucial part of changing law school culture, even if some positive changes have begun (such as programs in mental disability law and other public interest fields). The use of therapeutic

${ }^{85}$ For the classic work on the intersection between law and power, see Robert M. Cover, The Supreme Court, 1982 Term-Foreword: Nomos and Narrative, 97 HARV. L. REV. 4 (1983). For a consideration, through a therapeutic jurisprudence perspective, of how the power of the law can shame and humiliate (drawing on Cover's work), see Michael L. Perlin \& Naomi M. Weinstein, "Friend to the Martyr, a Friend to the Woman of Shame": Thinking About the Law, Shame, and Humiliation, 24 S. CAL. REV. L. \& SOC. JUST. 1 (2014).

${ }^{86}$ Gerald R. Wheeler \& Carol L. Wheeler, Reflections on Legal Representation of the Economically Disadvantaged: Beyond Assembly Line Justice, 26 CRIME \& DELINQ. 319, 319 (1980). See generally Michael L. Perlin \& Meredith R. Schriver, "You Might Have Drugs at Your Command": Reconsidering the Forced Drugging of Incompetent Pre-trial Detainees from the Perspectives of International Human Rights and Income Inequality, 8 ALB. Gov'T L. REV. 381 (2015).

${ }^{87}$ Youngberg v. Romeo, 457 U.S. 307, 316 (1982) ("Indeed, 'liberty from bodily restraint always has been recognized as the core of the liberty protected by the Due Process Clause from arbitrary governmental action." "); Vitek v. Jones, 445 U.S. 480, 491 (1980).

${ }^{88}$ See Stephen Wizner, Rationing Justice, 1997 AnN. SuRV. Am. L. 1019, 1025 (1997).

${ }^{89}$ See, e.g., Joel Haycock, Speaking Truth to Power: Rights, Therapeutic Jurisprudence, and Massachusetts Mental Health Law, 20 New ENG. J. ON CRIM. \& Civ. ConfINEMENT 301, 318 (1994).

${ }^{90}$ Wizner, supra note 66, at 261. 
jurisprudence as a teaching tool-especially in the context of a subject matter as controversial and as stereotyped as the sexual autonomy rights of persons with mental disabilities - is an integral part of that reformation process.

\section{CONCLUSION}

We must change the prevailing model of legal education. We believe we have a duty to steer some students towards careers in public interest, ${ }^{91}$ and to reenergize all law students in their studies. TJ is a teaching tool that can effectively force students - while reading cases - to keep the client in mind, help them better connect with the material, and best hone their legal skills. This mandate fits perfectly, we believe, with the way that we teach sexuality and disability.

We teach about sexuality rights in our Survey of Mental Disability Law course, and in our Therapeutic Jurisprudence course. We do this because we believe it is essential that our students confront these difficult questions of autonomy and social justice if they are to truly understand the deep textures of what they are studying. We also believe that the application of TJ values best illuminates the issues at hand. There is resistance on the part of many students (just as there is resistance on the part of faculty). But we will continue to articulate these views and to call out those whose sanism blinds them to the issues at hand.

There is some irony to be added. Some years ago, one of us (MLP) gave the keynote presentation at a SALT conference, and presented a paper titled, "Mental Disability, Sanism, Pretextuality, Therapeutic Jurisprudence, and Teaching Law." The hostile response to the talk was appalling. In an article subsequently published in the SALT Equalizer, Professor Rogelio Lasso wrote that he "found it particularly disturbing that 'Sane-ism' merited a plenary presentation" at a SALT conference. ${ }^{92}$ Why should SALT be interested in this when there were so many other social justice issues to consider? ${ }^{93}$ Traditional progressive voices have been as equally hostile as have reactionary voices when it comes to the issues discussed in our article, and in our classes, and that AJL asserts in practice. We are hoping that, this time, the response will be somewhat different.

\footnotetext{
${ }^{91}$ There has been little written about this topic. See, however, Richard F. Storrow \& Patti Gearhart Turner, Where Equal Justice Begins: Mandatory Pro Bono in American Legal Education, 72 UMKC L. REV. 493, 498-99 (2003) (citing Professor Deborah Rhode, who has complained that although the majority of law school deans agree there is a duty to encourage students to perform pro bono later in their careers, most students do not participate in pro bono projects).

${ }^{92}$ Rogelio Lasso, Diversity Is As Diversity Does, SALT EQUALIZER, Dec. 1994, at 18, 18 19.

${ }^{93}$ Seeid.
} 
